\title{
Okul Öncesi Öğretmenlerinin Alan Gezisi Etkinliğine Yönelik Görüşlerinin İncelenmesi
}

\author{
DOI: $10.26466 /$ opus.571498
}

\author{
* \\ Cansu Tutkun* - Zeynep Nur Aydın Kılıç⿳亠丷厂 - Aslı Balc1 ${ }^{* * *}-$ Mehmet Kök**** \\ * Dr. Öğr. Üyesi Bayburt Üniversitesi, Eğitim Fakültesi, Bayburt / Türkiye \\ E-Posta: cansututkun06@hotmail.com ORCID: 0000-0002-2722-2274 \\ ** Arş. Gör., Gazi Üniversitesi, Gazi Eğitim Fakültesi, Ankara/ Türkiye \\ E-Posta: zeynepnuraydin@gmail.com ORCID: 0000-0001-9182-5152 \\ *** Arş.Gör. Atatürk Üniversitesi, Kazım Karabekir Eğitim Fakültesi, Erzurum/ Türkiye \\ E-Posta: asli.balci@atauni.edu.tr ORCID: 0000-0003-4329-6588 \\ **** Doç. Dr. Alaadin Keykubat Üniversitesi, Eğitim Fakültesi, Alanya / Antalya/ Türkiye \\ E-Posta mehmet.kok@alanya.edu.tr ORCID: 0000-0001-6193-5545 \\ Öz
}

Bu çalışma okul öncesi öğretmenlerinin alan gezisi etkinlikleri hakkındaki görüşlerini incelemek amacıyla yapılmıştır. Çalışmada nitel araştırma yöntemlerinden durum çalışması kullanılmıştır. Araştırmanın çalışma grubunu 2016-2017 eğitim-öğretim yılında Erzurum İli merkezindeki anaokulu ve anasinıflarında görev yapan 30 okul öncesi öğretmeni oluşturmuştur. Araştırmada veri toplama aracı olarak yarı yapılandırılmış görüşme formu kullanılmıştır. Elde edilen veriler içerik analizi tekniğine göre çözümlenmiştir. Araştırma sonucunda öğretmenlerin çoğunlukla tiyatro, sinema ve müze gibi mekanlara gezi düzenledikleri, alan gezisi etkinliklerinin çocukların deneyimleyerek öğrenme, kahıı öğrenme, eğlenerek öğrenme gibi akademik becerilerine yönelik yararları olduğunu belirttikleri sonucuna ulaşılmıştır. Öğretmenlerin alan gezisi etkinlikleri kapsamında çoğunlukla maddi sorunlar, güvenlik endişesi, hastalık endişesi ve etkinliğin gereksiz bulunması gibi ailesel nedenlerden kaynaklı sorunlar yaşadıkları saptanmıştır. Öğretmenlerin gezi düzenlenecek alanları belirlerken gezi düzenlenecek alanın güvenli ve ulaşımının kolay olması, çocuklara yönelik eğitici, eğlenceli, ilgi çekici, gelişim düzeyine uygun olması gibi kriterleri göz önünde bulundurdukları belirlenmiştir. Öğretmenlerin gezi öncesinde gezi planı hazırlama, çocuklarla gidilecek yerin özellikleri hakkında sohbet etme, çocuklara uyulması gereken kurallar hakkında bilgi verme, çocuklarla gezinin amacı hakkında konuşma gibi etkinlikler yaptıkları belirlenmiştir. Diğer taraftan gezi esnasında öğretmenlerin çoğunluğunun herhangi bir etkinlik yaptırmadığı, gezi sonrasında çoğunlukla çocuklarla etkinlik yapmadan sadece sohbet ettikleri sonucuna ulaşılmıştır.

Anahtar Kelimeler: Okul öncesi eğitim, Alan gezisi etkinliği,Okul öncesi öğretmeni 


\title{
Examination of Preschool Teachers' Views about Field Trip Activities
}

*

\begin{abstract}
This study was conducted to examine the views of preschool teachers about field trip activities. In this study, a case study of qualitative research methods was used. The study group of the study was composed of 30 preschool teachers working in central kindergarten in Erzurum province in 2016-2017 academic year. In the study, semi-structured interview form was used as data collection tool. The data were analyzed according to the content analysis technique. At the end of the research, among the places where teachers had field trip activities, theater, cinema and museum were the most visited places, it was concluded that field trip activities indicate that children have academic skills such as experiential learning, permanent learning, entertaining learning. It was found that the teachers experienced problems due to family reasons such as financial problems, security concerns, illness anxiety and unnecessary activity. When determining the areas to be organized, it was determined that the area to be organized for the trip was safe and easy to access, educational, fun, interesting and appropriate for the children. It was determined that the teachers made activities such as preparing a trip plan before the trip, talking about the characteristics of the place to go with children, giving information about the rules to be followed, talking about the purpose of the trip with the children. On the other hand, during the field trip, it was concluded that the majority of the teachers did not take any activities and mostly talked with the children after the trip.
\end{abstract}

Keywords: Sports Center, Expectation, woman, Body Mass Index 


\section{Giriş}

Günümüzde eğitim sisteminin geleneksel anlayıştan giderek uzaklaşmasıyla birlikte eğitim ve öğretime yönelik çalışmalar mümkün olan her ortamda ve her firsatta evde, okulda ve okul dışında yaşam boyu devam eden bir sürece dönüşmüştür (Bozdoğan, 2012). Bu süreçte çocuklar için sağladığı yararların yapılan çalışmalarla ortaya konulmasıyla birlikte eğitsel aktiviteler olarak akvaryumlar, botanik bahçeleri, müzeler, bilim merkezleri, hayvanat bahçeleri gibi alanlarda gerçekleştirilen okul dışı etkinlikler de geçmişe oranla daha fazla ön plana çıkmıştır (Hannu, 1993; Subramaniam, Asim, Lee ve Koo, 2018). Alan gezisi etkinlikleri, eğitsel amaçlar doğrultusunda çocukların farklı ortamlarda deneyim kazanmaları olarak tanımlanmaktadır (Tal ve Morag, 2009).

Çocuklar için alan gezileri, nesneleri ve kavramları keşfetmek, sosyal ve doğal ortamlarda uygulamalar yapmak için sınıftan ayrılmak anlamına gelmektedir. Bu tarz otantik öğrenme ortamları çocuklar için anlamlı öğrenme ortamlarıdır. Alan gezileri çocuklara herhangi bir konu hakkında zengin bilgi sağlamasının yanında çocukların çeşitli beceri ve yeteneklerinin gelişmesine de yardımcı olmaktadır (Kızıltaş ve Sak, 2018a). Nitekim Okul Öncesi Eğitim Programının önemli özelliklerinden biri "günlük yaşam deneyimlerinin ve yakın çevre olanaklarının eğitim amaçlı kullanılmasını teşvik etmesidir" (MEB, 2013). Programın bu özelliğinden hareketle sınıf dışında ulaşılabilecek her alana "alan gezileri" düzenlenebilmektedir (Kefi, 2016). Bu sayede çocuklar, ortamı doğrudan gözlemleyebilmekte elde ettikleri deneyimleri içselleştirebilmektedir. Alan gezileri ile okul ortamı dışında farklı ortamlarda aktivitelere katılım imkanı bulmakta, yeni bilgiler ve beceriler kazanmakta, geçmiş öğrenmelerini ise pekiştirme şansını elde etmektedir (Lei, 2010). İyi bir şekilde planlanmış alan gezileri çocukların tüm gelişim alanlarının desteklenmesinde oldukça önemli bir role sahiptir (Kızıltaş ve Sak, 2018b; Singal ve Swann, 2011; Taylor, Morris ve Cordeau Young, 1997). Alan gezileri çocukların ilgilerini, bilgilerini ve motivasyonlarını artırmakta (Behrendt ve Franklin, 2014), bilimsel bilgilerin yanı sıra sosyal-duyuşsal beceriler ve düşünme becerilerini de geliştirmektedir (Rudmann, 1994). Bu sayede çocuklar araştırma, keşfetme, ilk elden bilgi edinme ve özgün deneyimler elde etme fırsatı bulmaktadır (DeWitt ve Storksdieck, 2008; Ramey-Gassert, 1997). 
Alan gezilerinin en temel unsurlarından biri öğretmenlerdir (Behrendt ve Franklin, 2014). Öğretmenlerin (a) geziden önce gezi düzenlenecek ortamı tanıması; (b) çocukları ortam ve konuya yönlendirme ve öğrenme hedeflerini netleştirmesi; (c) müfredat hedefleri ile uyumlu ziyaret öncesi etkinlikleri planlaması; (d) çocukların ziyaret sırasında araştırma ve keşfetme zamanına izin vermesi; (e) müfredatı destekleyen etkinlikleri planlama, ayrıca ortamın benzersizliğinden yararlanması; (f) alan gezisi deneyimini pekiştirme, çocuklara paylaşım ve geribildirim için fırsatlar sağlamak amacıyla ziyaret sonrası sınıf etkinliklerini planlaması ve yürütmesi gerekmektedir (DeWitt ve Storksdieck, 2008). Alan gezisi sırasında ortamda geçirilen gerçek zaman miktarı sınırlıdır, bu nedenle öğretmenlerin geçirilen zamanın değerini en üst düzeye çıkarmak için, geziye çıkmadan önceki günlerde çocuklara oryantasyon sağlaması, çocukların gezi öncesi ve sonrasında öğrendikleriyle yapılan etkinlikler arasında bağlantı kurması önemlidir (Meiers, 2013).

Alan gezisi etkinliklerinin amacına ulaşması ve etkili olma düzeyi iyi planlanmasına ve yapılandırılmasına bağlıdır. Konu ile ilgili literatür incelendiğinde ideal bir alan gezisinin, yalnızca gezi esnasında yapılacak aktivitelerle sınırlı kalmayıp, gezi öncesi ve gezi sonrası şeklinde planlanarak bütüncül bir yaklaşımla ele alınması gerektiği görülmüştür (Bitgood, 1989; Taylor vd., 1997; Woerner, 1999). Nitekim alan gezileri ancak; gezi öncesi gerekli koşulların hazırlanması ve gezi düzenlenecek yer ile ilgili farkındalık oluşturulması, belirli bir plan doğrultusunda gerçekleştirilmesi ve gezi sonrasında yapılan değerlendirme süreciyle gerekli kazanımlara ulaşabilen bir etkinliktir. Ayrıca öğretmenlere sorumluluk yükleyen ve yasal sorumluluğu fazla olan bunun yanında iyi planlanmadığında ise başarı sağlamanın zor olduğu bir etkinliktir. Bu açıdan bakıldığında okul öncesi öğretmenlerinin alan gezisi etkinliklerine ilişkin bilgi ve alg1larının, etkinlikleri ne şekilde düzenlediklerinin detaylı bir şekilde incelenmesi önemlidir. Ayrıca bu konuyla ilgili yapılan çalışmaların az sayıda olmasından dolayı (Koç ve Sak, 2017) okul öncesi dönemde yapılan alan gezisi etkinliklerine dikkat çekilmesi açısından alana katkı sağlayacağı düşünülmektedir. Bu noktadan hareketle bu araştırma, okul öncesi öğretmenlerinin alan gezisi hakkındaki görüşlerini ele almak amacıyla yapılmiştır. 


\section{Yöntem}

Bu araştırma, okul öncesi öğretmenlerinin alan gezisi etkinliklerine ilişkin görüşlerini incelemek amacıyla nitel araştırma modelinde desenlenmiştir. Nitel araştırmanın öncelikli amacı bir durumu ya da bir olguyu katılımc1ların nasıl anlamlandırdıklarını ortaya çıkarmak ve yorumlamaktır (Merriam, 2013).

\section{Çalışma Grubu}

Araştırmada öğretmenlerin alan gezisi etkinliklerine yönelik görüşlerinin belirlenmesinde derinlemesine çalışmaya olanak veren (Yıldırım ve Şimşek, 2006) amaçlı örneklem yöntemlerinden ölçüt örnekleme stratejisi kullanılmıştır. Amaç, ölçüt bir örneklem oluşturma yoluyla daha önceden belirlenmiş bazı önem ölçütlerini karşılayan tüm durumları çalışmak ve gözden geçirmektir (Patton, 2014). Katılımcların çalışmanın amacına uygun kişiler olup olmadıklarının belirlenip bu durumun sağlama alınması araştırmanın güvenilir olması bakımından önem taşımaktadır. Bu sebeple bu araştırmada öğretmenlerin alan gezisi etkinlikleri yaptırma durumu ölçüt olarak belirlenmiş olup eğitim öğretim etkinlikleri kapsamında alan gezisi etkinliklerine yer veren okul öncesi öğretmenleriyle görüşmeler yapılmıştir.

Araştırmanın çalışma grubunu 2016-2017 eğitim-öğretim yılında Erzurum İli merkezindeki anaokulu ve anasınıflarında görev yapan 30 öğretmen oluşturmuştur. Çalışmaya katılan öğretmenlerin $26^{\prime}$ sı lisans, $4^{\prime}$ ü ön lisans mezunu ve 19' u beş-altı yaş grubu çocuklarla, 11' i üç-dört yaş grubu çocuklarla çalışmaktadır. Öğretmenlerin 10'u bir-beş yıl, 14'ü altıon yıl ve 6 'sı ise on bir-on beş yıl aralığında mesleki deneyime sahiptir.

\section{Veri Toplama Araçlan}

Araştırmada veri toplama aracı olarak, araştırmacılar tarafından hazırlanan yarı yapılandırılmış görüşme formu kullanılmıştır. Görüşme formunda "Alan gezisi etkinliklerinin çocuklar açısından yararlarının ne olduğu?" ve "Alan gezisi planlamasında dikkat ettikleri kriterlerin ne olduğu?" gibi sorular yer almaktadır. Yarı yapılandırılmış görüşme formu 
hazırlanma sürecinde önce ilgili alan yazın taraması yapılmıştır. Hazırlanan görüşme formuna ilişkin üç alan uzmanından soruların anlaşılabilirliği ve amaca hizmet etme durumunu belirlemek amacıyla görüş alınmıştır. Ardından çalışma grubu dışındaki üç öğretmene pilot uygulama yapılarak görüşme formuna son şekli verilmiştir.

\section{Verilerin Analizi}

Araştırmada veriler öğretmenlerle yapılan yüz yüze görüşmeler yoluyla toplanmıştır. Yapılan bu görüşmeler ses kayıt cihazı ile kayıt altına alınmıştır. Araştırmanın veri analiz sürecinde öncelikle ses kayıtlarının transkript edilme işlemi gerçekleştirilmiştir. Bu işlemle birlikte veriler yazılı bir formata dönüştürülmüştür. Ardından elde edilen verilen nitel araştırma yöntemlerinden içerik analizi yöntemiyle çözümlenmiştir. İçerik analizi sözel, yazılı ve diğer materyallerin içerdiği mesajı, anlam ve dilbilgisi açısından nesnel ve sistematik olarak sınıflandırma, sayılara dönüştürme ve çıkarımda bulunma yoluyla sosyal gerçeği araştıran bilimsel bir yaklaşımdır (Tavşancıl ve Aslan, 2001). Bu analiz; genel olarak bir veri setindeki örüntüler, temalar ve kategorilerin ortaya çıkarılması olarak ifade edilmektedir (Patton, 2002). Araştırmadan elde edilen veriler, kodlardan yola çıkarak temalar ve kategoriler altında toplanmıştır. Katılımcıların yanıtları italik yazıyla yazılmış ve alıntının yapıldığı veri numarası parantez içinde verilmiştir.

\section{Bulgular}

Araştırmaya katılan okul öncesi öğretmenlerinin alan gezisi etkinliklerini düzenlendikleri alanlara ilişkin sonuçlar Tablo 1'de bulunmaktadır.

Tablo 1 incelendiğinde öğretmenlerin alan gezisi düzenledikleri yerlerin en çok tiyatro, sinema, müze gibi sanatsal mekanlar olduğu görülmektedir. 
Tablo 1. Öğretmenlerin Alan Gezisi Düzenlediği Mekanlar

\begin{tabular}{lll}
\hline Temalar & Kategoriler & f \\
\hline \multirow{3}{*}{ Sanatsal Mekanlar } & Tiyatro & 21 \\
& Sinema & 17 \\
& Müze & 16 \\
\cline { 2 - 3 } Açık Hava Mekanları & Park-Bahçe & 12 \\
& Şenlik Alanları & 3 \\
& Orman & 2 \\
\cline { 2 - 3 } Mesleki Mekanlar & Hastane-Sağlık Ocağı & 6 \\
& Market-Pazar & 3 \\
& İtfaiye & 2 \\
& Postane & 2 \\
& Firın & 2 \\
& Rehabilitasyon merkezi & 2 \\
Eğitimsel Mekanlar & Karakol & 1 \\
\cline { 2 - 3 } & Kütüphane & 2 \\
& Üniversite & 1 \\
\hline
\end{tabular}

Öğretmenlerin alan gezisi etkinliklerinin yararlarına ilişkin görüşlerine ait bulgular Tablo 2' de yer almaktadır.

Tablo 2. Öğretmenlerin Alan Gezisi Etkinliklerinin Yararlarına ilişkin Görüşleri

\begin{tabular}{lll}
\hline Temalar & Kategoriler & f \\
\hline \multirow{3}{*}{ Akademik } & Deneyimleyerek öğrenme & 16 \\
& Kalıc öğrenme & 9 \\
& Eğlenerek öğrenme & 8 \\
& Farklı yerleri görme fırsatı & 2 \\
& Genel kültür bilgisi & 1 \\
& Toplumsal kuralları öğrenme & 1 \\
\cline { 2 - 3 } Gelişimsel & Özgüven gelişimi & 3 \\
\hline
\end{tabular}

Tablo 2'de görüldüğü gibi öğretmenler çoğunlukla alan gezisi etkinliklerinin çocukların deneyimleyerek öğrenme, kalıcı öğrenme, eğlenerek öğrenme gibi akademik becerilerine yönelik yararları olduğunu belirttikleri görülmektedir. Bu konuya ilişkin bazı öğretmenlerin ifadeleri şu şekildedir:

- "Toplu yerlerde nasil davranilması gerektiği ve birlikte nasil hareket edilmesi ile ilgili davranış kazanıyorlar. Görerek yaparak yaşayarak öğreniyorlar. Gittiğimiz yerler bizim için bile şaşırtıcı olabiliyor" (Ö27). 
- "Her şeyden önce çocuklar çok eğleniyor ve görerek daha aktif öğreniyorlar." (Ö16).

Diğer taraftan çok az sayıda öğretmen ise, alan gezilerinin çocukların özgüven gelişimlerini destekleme açısından yararlı olduğunu belirtmiştir.

Okul öncesi öğretmenlerinin alan gezisi etkinleri açısından yaşadıkları sorunlara ilişkin görüşleri Tablo 3' de yer almaktadır.

Tablo 3. Alan Gezisi Etkinlikleri Kapsamında Yaşanılan Sorunlar

\begin{tabular}{lll}
\hline Temalar & Kategoriler & f \\
\hline \multirow{3}{*}{ Ailesel Sorunlar } & Maddi sorunlar & 10 \\
& Güvenlik endişesi & 7 \\
& Hastalı endişesi & 6 \\
Okuldan Kaynaklanan Sorunlar & Etkinliğin gereksiz bulunması & 2 \\
\cline { 2 - 3 } İklimsel Sorunlar & İzin sorunu & 4 \\
\cline { 2 - 3 } & Şehrin iklim koşulları & 3 \\
\hline
\end{tabular}

Tablo 3 incelendiğinde öğretmenlerin alan gezisi etkinlikleri kapsamında çoğunlukla maddi sorunlar, güvenlik endişesi, hastalık endişesi ve etkinliğin gereksiz bulunması gibi ailesel nedenlerden kaynaklı sorunlar yaşadıklarını belirttikleri görülmektedir. Öğretmenlerden bazıları ise izin almada sorun yaşanması gibi okul yönetiminden ve şehrin iklim koşullarının çok soğuk olması gibi iklimden kaynaklı olarak problem yaşadıklarını ifade etmişlerdir. Öğretmenlerin bu konuya yönelik olarak görüşleri şu şekildedir:

- "Güvenliği sağladığımı ölçüde idare sıkıntı çıkarmıyor fakat veliler ödenecek ücret konusunda oldukça sıkıntı çıkarıyor istemiyorlar" (Ö6).

- “Uzak yerlere aileler göndermek istemiyor (Ö19).

- "İdare kaynaklı sorun yaşıyoruz. Prosedür yoğun olduğu için izin zor çıkıyor. Aileler maddi yönden sıkıntı çıarıyorlar" (Ö5).

Öğretmenlerin alan gezisi planlamasında dikkat ettikleri kriterlere ilişkin görüşlerinin yer aldığ ${ }_{1}$ bulgular Tablo 4'de yer almaktadır. 
Tablo 4. Alan Gezisi Planlamasında Dikkat Edilen Kriterlere İlişkin Görüşler

\begin{tabular}{lll}
\hline Temalar & Kategoriler & $\mathbf{f}$ \\
\hline Gezi Alanına Yönelik & Güvenli olması & 12 \\
& Ulaşımın kolay olması & 4 \\
\cline { 2 - 3 } Çocuklara Yönelik & Eğitici olması & 8 \\
& Eğlenceli olması & 5 \\
& Gelişim düzeyine uygun olması & 4 \\
& İlgi çekici olması & 4 \\
\cline { 2 - 3 } Müfredata Yönelik & Kazanım- gösterge ve kavramlara uygun olması & 7 \\
& Belirli gün ve haftaya uygun olması & 6 \\
\hline
\end{tabular}

Tablo 4 incelendiğinde öğretmenlerin gezi düzenlenecek alanları belirlerken gezi alanlarına, çocuklara ve müfredata yönelik kriterleri göz önünde bulundurdukları görülmektedir. Gezi düzenlenecek alanın güvenli ve ulaşımının kolay olması gibi gezi alanına yönelik öğretmenlerin verdikleri yanıtlardan bazıları şu şekildedir:

- "..........Bir de ulaşımı kolay mı ya da şartları bizi zorlayacak mı ona bakıyoruz" (Ö9).

- "Önce güvenli olmasına dikkat ediyorum. Çocuklar için tehlikeli olup olmadığına bakıyorum. Rahat hareket edebilecekleri yer olmasına dikkat ediyorum (Ö22).

Öğretmenlerden bazılarının ise; çocuklara yönelik eğitici, eğlenceli, ilgi çekici, gelişim düzeyine uygun olması ve müfredata yönelik kazanımgösterge ve kavramlara, belirli gün ve haftaya uygun olması gibi kriterleri gezi alanlarını belirlerken göz önünde bulundurdukları görülmektedir. Konuya ilişkin bazı öğretmenlerin yanıtları şöyledir:

- "Gittiğimiz yerdeki uyaranların zengin olmasına ve çocuklara fayda să̆lamasina da önem veriyorum" (Ö22).

- "Planıma göre o günkü etkinliği destekleyecek yerleri tercih ediyorum. Mesela itfaiye haftasinda itfaiyeye götürmüştük" (Ö23).

Öğretmenlerin alan gezisi sürecinde yaptıkları etkinliklere ilişkin görüşleri Tablo 5'de sunulmuştur. 
Tablo 5. Alan Gezisi Sürecinde Yapılan Etkinlilere İlişkin Görüşler

\begin{tabular}{lll}
\hline Temalar & Kategoriler & f \\
\hline \multirow{4}{*}{ Gezi öncesinde } & Gezi planı hazırlama & 26 \\
& Çocuklarla sohbet etme & 22 \\
& Çocuklara kurallar hakkında bilgi verme & 19 \\
& Çocuklarla gezinin amacı hakkında konuşma & 6 \\
\hline \multirow{5}{*}{ Gezi sırasında } & Etkinlik yapılmıyor & 21 \\
& Oyun & 5 \\
& Drama & 5 \\
& Fen & 4 \\
\hline \multirow{5}{*}{ Gezi sonrasında } & Sohbet etme & 25 \\
& Sanat etkinliği & 21 \\
& Drama etkinliği & 6 \\
& Türkçe etkinliği & 2 \\
\hline
\end{tabular}

Tablo 5 incelendiğinde gezi öncesinde öğretmenlerin gezi planı hazırlama, çocuklarla gidilecek yerin özellikleri hakkında sohbet etme, çocuklara uyulması gereken kurallar hakkında bilgi verme, çocuklarla gezinin amacı hakkında konuşma gibi etkinlikler yaptıkları belirlenmiştir. Bu konuda öğretmenlerin bazıları görüşlerini şu şekilde ifade etmiştir:

- "Mutlaka gitmeden önce bilgilendiriyorum. Fotoğraflarla destekliyorum. Nedenlerini anlatıyorum" (Ö4).

- "Nasıl davranmamiz gerektiğini konuşup beyin firtınası yapıyoruz. Kuralları belirliyoruz. Güvenlik üzerine konuşuyoruz" (Ö8).

- "Gideceğimiz yer hakkında kesinlikle bilgi veriyorum. Orayla alakalı yapmamiz gereken veya yapmamamiz gereken durumlar hakkında bilgi veririm. Çok çok iyi incelemeleri gerektiğini dönüşte bununla ilgili resim yapacağımızı sorular soracağımı söylerim ve ilgilerini artırırım" (Ö10).

Diğer taraftan gezi esnasında öğretmenlerin çoğunluğunun herhangi bir etkinlik yaptırmadığını belirttikleri görülmektedir. Buna ilişkin bazı öğretmenlerin ifadesi şöyledir:

- "Gezi sırasında etkinlik yapmıyoruz, çünkü zaman kısıtlı" (Ö6).

- "Hayır, gittiğimiz yerler çoğunlukla etkinlik yapmak için uygun olmuyor." (Ö20). 
Gezi sırasında etkinlik yaptıklarını belirten öğretmenler ise, gezi yapılan alanda oyun, drama ve fen etkinliklerini yaptırdıkları yönünde görüş bildirmişlerdir. Buna ilişkin bazı öğretmen görüşleri şu şekildedir:

- "Mesela en son sonbahar gezisi yapmıştı. Yaprak topladık ve o yapraklarla daha sonra sonbahar ă̆acı oluşturduk" (Ö21).

- "Son düzenlediğimiz gezilerden birinde açık havada ilkbahar konulu bir drama yaptık. Çocuklar önce çevreyi gözlemledi. Sonra drama yaptık" (Ö22).

- "Mesela botanik bahçesine gittiğimizde yanımızda büyüteç götürmüştük. Bitkilerin şekillerini topraktaki küçük canlıları incelemiştik" (Ö27).

Öğretmenlerin gezi sonrasında çoğunlukla çocuklarla etkinlik yapmadan çocuklarla sadece sohbet ettikleri, ayrıca bazı öğretmenlerin de sanat, drama, Türkçe ve müzik gibi etkinlikler düzenledikleri saptanmıştır. Bu konudaki öğretmen görüşlerinden bazıları şu şekildedir:

- "Evet, geldikten sonra neler gördünüz, size bilgi veren kişi kimdi, ne anlattı tarzında sohbet ediyoruz. Ayn gün içinde yapıyoruz değerlendirmeyi. Okula dönerken araçta başlıyoruz değerlendirmeye" (Ö28).

- "Dönüşte etkinlik yapmaya pek firsatım olmuyor. Dönüşümüz çıkış saatine denk geldiği için çocukları aileleri alıyor. Etkinlik için zamanımız kalmıyor" (Ö30).

- "O gün içinde olmasa bile diğer günlerde yapıyoruz. Çünkü vakit kalmıyor. Beğendiniz mi? orda ne gördük gibi?" (Ö2).

- "Evet, gezdiği gördü̆̆̈̈n yerin resmini yaptırıyorum" (Ö1).

- "Gördükleri şeylerin resmini çizmelerini istiyorum. Bazen drama yaptlrıyorum" (Ö22).

\section{Tartışma, Sonuç ve Öneriler}

Okul öncesi öğretmenlerinin alan gezisi etkinliklerine yönelik görüşlerinin incelendiği bu araştırma sonucunda öğretmenlerin çoğunlukla tiyatro, sinema ve müze gibi mekanlara gezi düzenledikleri belirlenmiştir. Araştırmada alan gezisi etkinliklerinin çocukların deneyimleyerek öğrenme, 
kalıcı öğrenme, eğlenerek öğrenme gibi akademik becerilerine, çok az sayıda öğretmen ise, çocukların özgüven gelişimlerini desteklemeye yönelik yararları olduğunu belirttikleri sonucuna ulaşılmıştır. Yapılan araştırmalar alan gezilerinin eğitimsel açıdan birçok yararının bulunduğunu ortaya koymaktadır (Bozdoğan, Okur ve Kasap, 2015; Greene, Erickson, Watson ve Beck, 2018; Kızıltaş ve Sak, 2018a). Alan gezisine yönelik bir araştırmada öğrencilerin yaparak yaşayarak edindikleri bilgilerin kalıcılığının yüksek olduğu, öğrencilerin ilgili, meraklı ve öğrenmeye istekli oldukları, ilk elden gözlem yapma ve bilgi alma imkânı buldukları ve bu tür geziler düzenlenmesinin daha eğlenceli olduğu sonucuna ulaşılmıştır (Bozdoğan, Okur ve Kasap, 2015).

Öğretmenlerin alan gezisi etkinlikleri kapsamında çoğunlukla maddi sorunlar, güvenlik endişesi, hastalık endişesi ve etkinliğin gereksiz bulunması gibi ailesel nedenlerden kaynaklı sorunlar yaşadıkları, bazılarının ise izin almada sorun yaşanması gibi okul yönetiminden ve şehrin iklim koşullarının çok soğuk olması gibi iklimden kaynaklı olarak sorun yaşadıkları saptanmıştır. Bu sonuçlar doğrultusunda öğretmenlerin alan gezilerinin düzenlenmesinde öncelikle anne babalardan kaynaklanan sorunlar yaşandığını belirttikleri görülmektedir. Bu durumun alan gezisi etkinliğine ailelerin çok fazla dahil edilmemiş ve etkinliğin yararlarına ilişkin çok fazla farkındalıklarının oluşturulmamış olmasından kaynaklandığı düşünülebilir. Nitekim alan gezisi etkinliklerine anne babaların dahil edilerek gerçekleştirilen bir araştırmada, anne-babalar bu etkinliklerin çocukların bilişsel, duygusal, sosyal, motor ve dil gelişimlerine olumlu yönde etkilerinin olduğunu belirttikleri ve bu etkinliklerin çok yararlı olduğunu ifade ettikleri sonucuna ulaşılmıştır (Kızıltaş ve Sak, 2018a). Bu bağlamda alan gezisi etkinliklerine anne babaların dahil edilmesinin hem onların süreç hakkında farkındalık oluşturmaları hem de bu etkinliklerin çocuklarının gelişiminde önemli olduğuna ilişkin bilgi edinmeleri açısından önemli bir unsurdur. Diğer taraftan alan gezisi hakkında olumlu tutum benimseyen anne babalar, süreçte öğretmene de destek sağlayarak, alan gezisi etkinliklerinin gerçekleştirilmesinde kolaylaştırıcı ve destekleyici bir unsur olarak düşünülebilir.

Öğretmenlerin gezi düzenlenecek alanları belirlerken gezi düzenlenecek alanın güvenli ve ulaşımının kolay olması, çocuklara yönelik eğitici, eğlenceli, ilgi çekici, gelişim düzeyine uygun olması ve müfredata yönelik 
kazanım- gösterge ve kavramlara, belirli gün ve haftaya uygun olması gibi kriterleri göz önünde bulundurdukları belirlenmiştir. Alan gezilerinde dikkat edilmesi gereken noktalardan biri alanın güvenli olmasıdır (Güven, Gazel, \& Sever, 2004). Uzbilir Özçelik (2018) tarafından yapılan araştırmada okul öncesi ve sınıf öğretmenlerinin alan gezisi yapmaktan alıkoyan nedenler arasında ulaşım zorluğu, güvenlik, öğrenci kontrolü, akademik program gibi etkenlerin yer aldığı belirlenmiştir. Erata (2018) tarafından yapılan araştırmada ise okul öncesi öğretmenlerinin alan gezisi düzenlenecek yer seçiminde öncelikle kazanım ve göstergeleri dikkate aldıkları, alan gezilerinin zamanını belirlerken ise özel gün ve haftalar takviminin tercih edildiği, alan gezisi yapılacak mekân olarak yakın çevre gezileri tercih edildiği görülmüştür. Bu bağlamda bu araştırmadan elde edilen sonuçların diğer araştırma sonuçlarıyla paralellik gösterdiği ve öğretmenlerin alan gezisi düzenlerken ulaşım ve güvenlik gibi alana, çocuklara ve müfredata yönelik kriterleri göz önünde bulundurmalarının, etkili bir alan gezisi düzenlenmesinde önemli unsurlar olduğu söylenebilir.

Öğretmenlerin gezi öncesinde gezi planı hazırlama, çocuklarla gidilecek yerin özellikleri hakkında sohbet etme, çocuklara uyulması gereken kurallar hakkında bilgi verme, çocuklarla gezinin amacı hakkında konuşma gibi etkinlikler yaptıkları belirlenmiştir. Diğer taraftan gezi esnasında öğretmenlerin çoğunluğunun herhangi bir etkinlik yaptırmadığı, gezi sonrasında çoğunlukla çocuklarla etkinlik yapmadan sadece sohbet ettikleri sonucuna ulaşılmıştır. Bunun yanında gezi sonrası yapılan etkinliklerin çoğunluk olarak gidilen yerin resmini yaptırmayı amaçlayan sanat etkinlikleri ile sınırlı kaldığı saptanmıştır. DeWitt ve Osborne (2007), alan gezisi düzenlenecek ortamların önemli eğitim kaynakları olmasına rağmen, buralardaki etkinliklerin genellikle öğrenmeyi en üst seviyeye çıaracak şekilde planlanmadığını belirtmektedir (DeWitt ve Osborne, 2007). Bununla birlikte, alan gezileri basit bir şekilde gerçekleşmemektedir. Öğretmenlerin bu tür aktivitelerin öğrenme deneyimini en üst düzeye çıkarmak için organizasyon, planlama ve değerlendirme gerektirdiğini göz önünde bulundurmaları (Behrendt ve Franklin, 2014) ve çocukları koordine etmeleri ve etkili bir şekilde alan gezisini idare edebilmeleri açısından yeterli mesleki yeteneğe ve bilgiye sahip olması gerekmektedir (Kandır, Yurt, Cevher-Kalburan, 2012). Bu bağlamda alan gezilerinin etkili ola- 
bilmesi için öğretmenlerin bu etkinlikleri çok iyi planlamalarının, gezi s1rasında ve sonrasında farklı etkinlikler düzenleyerek çocukların öğrenmelerini en üst seviyeye çıkarmalarının önemli olduğu düşünülmektedir.

Araştırmada öğretmenlerin görüşleri doğrultusunda elde edilen sonuçlar dikkate alındığında alan gezisi etkinliğinin amacına ulaşmasında kritik bir öneme sahip olan gezi esnası-sonrası farklı ve yaratıcı etkinliklerin yapılması yönünde okul öncesi öğretmenlerine yönelik farkındalık çalışmalarının; ailelerin etkinliğe yönelik özellikle güvenlik endişelerinin giderilmesine amacıyla bilgilendirme toplantılarının yapılması önerilmektedir. Etkinliğin yapılmasına yönelik olarak belirtilen maddi sorunların giderilmesine amacıyla okulların gezi etkinliği için bütçe ayırması önerilebilir 


\title{
EXTENDED ABSTRACT
}

\section{Examination of Preschool Teachers' Views about Field Trip Activities}

\author{
M.Eyüp Uzuner - Levent Atalı - Betül Bayazıt - Hacı Ağdaş \\ Bayburt University, Gazi University, Atatütk University, Alaeddin Keykubat University
}

Nowadays, as the education system is gradually getting away from the traditional approach, education and training activities have turned into a lifelong process at home, school and outside school at every opportunity and at every opportunity (Bozdoğan, 2012). In this process, with the help of the studies provided for children, educational activities such as aquariums, botanical gardens, museums, science centers, zoological gardens, etc. have also become more prominent (Hannu, 1993; Subramaniam, Asim, Lee ve Koo, 2018).

The purpose of the field trip activities and the level of effectiveness depends on the good planning and construction. When the literature on the subject is examined, it is seen that an ideal field trip should not be limited to the activities to be done during the trip, but should be planned with a holistic approach before and after the trip (Bitgood, 1989; Taylor vd., 1997; Woerner, 1999). Indeed, field trips but; preparing the necessary conditions before the trip and creating awareness about the place where the trip will be organized is an activity that can be achieved in accordance with a specific plan and can achieve the necessary gains through the evaluation process after the trip. It is also an activity where it is difficult to achieve success when the teachers are responsible for the responsibility and the legal responsibility is high. From this point of view, it is important to examine in detail how the knowledge and perceptions of pre-school teachers about field-trip activities are organized. From this point of view, this research was carried out to discuss the views of pre-school teachers about the field trip.

In this study, a case study of qualitative research methods was used. The primary objective of qualitative research is to reveal and interpret how a participant makes sense of a situation or a phenomenon (Merriam, 2013). The status of teachers in making field trip activities was determined 
as the criterion and interviews were conducted with pre-school teachers who included field trip activities within the scope of educational activities. The study group of the study was composed of 30 preschool teachers working in central kindergarten in Erzurum province in 2016-2017 academic

year.

Data were collected through face-to-face interviews with teachers. These interviews were recorded with a voice recorder. In the study, semi-structured interview form was used as data collection tool. The data were analyzed according to the content analysis technique. In the data analysis process of the research, transcription of the audio recordings was performed. With this process, the data were converted into a written format.

At the end of the research, among the places where teachers had field trip activities, theater, cinema and museum were the most visited places, it was concluded that field trip activities indicate that children have academic skills such as experiential learning, permanent learning, entertaining learning. It was found that the teachers experienced problems due to family reasons such as financial problems, security concerns, illness anxiety and unnecessary activity. In this context, it is important for parents to be involved in field trip activities, both to raise awareness of the process and to learn about the importance of these activities in the development of their children. On the other hand, parents who adopt a positive attitude about the field trip can be considered as a facilitating and supportive element in the field trip activities by providing support to the teacher in the process.

When determining the areas to be organized, it was determined that the area to be organized for the trip was safe and easy to access, educational, fun, interesting and appropriate for the children. It was determined that the teachers made activities such as preparing a trip plan before the trip, talking about the characteristics of the place to go with children, giving information about the rules to be followed, talking about the purpose of the trip with the children. On the other hand, during the field trip, it was concluded that the majority of the teachers did not take any activities and mostly talked with the children after the trip.

Considering the results obtained in line with the opinions of the teachers in the research, awareness studies for preschool teachers towards making different and creative activities during and after the trip are of critical 
importance for the purpose of field trip effectiveness; It is recommended that information meetings should be held with the aim of eliminating the security concerns of the families. In order to eliminate the financial problems mentioned in the activity, budget allocation for schools' activity can be suggested.

\section{Kaynakça / References}

Behrendt, M. ve Franklin, T. (2014). A Review of research on school field trips and their value in education. International Journal of Environmental and Science Education, 9, 235-245.

Bitgood, S. (1989). School field trips: An overview. Visitor Behavior, 4(2), 3-6.

Bozdoğan, A. E. (2012). Eğitim amaçlı gezilerin planlanmasına ilişkin fen bilgisi öğretmen adaylarının uygulamaları: Altı farklı alan gezisinin değerlendirilmesi. Kuram ve Uygulamada Eğitim Bilimleri, 12(2), 10501072.

Bozdoğan, A. E., Okur, A. ve Kasap, G. (2015). Planlı bir alan gezisi için örnek uygulama: Bir Fabrikası gezisi. Karadeniz Sosyal Bilimler Dergisi, 7(2), 79-90.

DeWitt, J., ve Storksdieck, M. (2008). A short review of school field trips: Key findings from the past and implications for the future. Visitor Studies, 11(2), 181-197. doi:10.1080/10645570802355562.

DeWitt, J., ve Osborne, J. (2007). Supporting teachers on science-focused school trips: Towards an integrated framework of theory and practice. International Journal of Science Education, 29(6), 685-710. doi:10.1080/09500690600802254.

Erata, F. (2018). Okul öncesi eğitimde alan gezilerinin uygulanmasına iliş̧in öğretmen görüşlerinin incelenmesi. Yayınlanmamış Yüksek Lisans Tezi, Selçuk Üniversitesi Sosyal Bilimler Enstitüsü, Konya.

Greene, J. P., Erickson, H. H., Watson, A. R., ve Beck, M. I. (2018). The play's the thing: Experimentally examining the social and cognitive effects of school field trips to live theater performances. Educational Researcher, 47(4), 246-254. doi:10.3102/0013189x18761034.

Güven, A., Gazel, A. A., ve Sever, R. (2004). Tarih öğretmenlerinin gezi- gözlem uygulamalarında karşılaştıkları sorunlar. Kazım Karabekir Eğitim Fakültesi Dergisi, 9, 225-235. 
Hannu, S. (1993). Science centre education: Motivation and learning in informal education. Unpublished doctoral dissertation, Helsinki University Department of Teacher Education, Finland.

Kandır, A., Yurt, Ö., ve Kalburan, N. (2012). Comparison of teachers and teacher candidates in terms of their environmental attitudes. Educational Sciences: Theory \& Practice, 12(1), 323-327.

Kefi, S. (2016). Alan gezilerinde okul öncesi öğretmenlerinin temel bilimsel süreç becerilerini kullanmalarının desteklenmesi, Uluslararası Eğitim Bilimleri Dergisi, 3(6), 82-103.

Kızıltaş, E. ve Sak, R. (2018a). Anne-babaların perspektifinden alan gezisi etkinlikleri. Trakya Ĕ̈itim Dergisi, 8(3), 468-480.

Kızıltaş, E. \& Sak, R. (2018b). Integrating field-trip activities with other activities in the preschool curriculum: Its effects on the preschoolers' socialemotional skills, International Journal of Child Care and Education Policy, 12(8), 2-17. doi.org/10.1186/s40723-018-0047-0

Koç, F., ve Sak, R. (2017). Okul öncesi öğretmenlerinin okul öncesi eğitim programındaki etkinliklere yönelik öz- yeterlik inançlarının incelenmesi. Uludă̆ Üniversitesi Eğitim Fakültesi Dergisi, 30(1), 43-71.

Lei, S. A. (2010). Assessment practices of advanced field ecology courses. Education, 130(3), 404-415.

MEB, (2013). Okul öncesi eğitim programı. Ankara: MEB Basımevi.

Meiers, N. J. (2013). Designing effective field trips at zoos and aquariums. Vermont: Middlebury College.

Merriam, S. B. (2013). Nitel araştırma desen ve uygulama için bir rehber, (S. Turan Çev.), Ankara: Nobel.

Patton, M.Q. (2002). Two decades of developments in qualitative inquiry: A personal, experiential perspective. Qualitative Social Work, 1(3), 261283.

Patton, M. Q. (2014). Nitel araştırma ve değerlendirme yöntemleri (M. Bütün ve S. B. Demir, çev.). Ankara: Pegem Akademi.

Ramsey-Gassert, L. (1997). Learning science beyond the classroom. Elementary School Journal, 97(4), 433-450.

Rudmann, C. L. (1994). A review of the use and implementation of science field trips. School Science and Mathematics, 94(3), 138-141.

Singal, N., ve Swann, M. (2011). Children's perceptions of themselves as learner inside and outside school. Research Papers in Education, 26(4), 469484. https://doi.org/10.1080/02671520903281617. 
Subramaniam, K., Asim, S., Lee, E. Y., ve Koo, Y. (2018). Student teachers' 1mages of science instruction in informal settings: A focus on field trip pedagogy. Journal of Science Teacher Education, 29(4), 307325.doi:10.1080/1046560x.2018.1452531.

Tal, T. ve Morag, O. (2009). Reflective practice as a means for preparing to teach outdoors in an ecological garden. Journal of Science Teacher Education, 20(3), 245-262.

Tavşancıl, E. ve Aslan E. (2001). İ̧erik analizi ve uygulama örnekleri. İstanbul; Epsilon.

Taylor, S. I., Morris, V., ve Cordeau Young, C. (1997). Field trips in early childhood settings: Expanding the walls of the classroom. Early Childhood Education Journal, 25(2), 141-146.

Uzbilir Özçelik, G. (2018). Okul öncesi ve sını öğretmenlerinin bilimsel alan gezisi yapmaya ilişkin öz-yeterliklerinin ve yaparken yaşadıkları zorluklar hakkında görüşlerinin incelenmesi. Yayımlanmamış Yüksek Lisans Tezi. İstanbul Aydın Üniversitesi Sosyal Bilimler Enstitüsü, İstanbul.

Woerner., J. J. (1999). The field trip in the earth science classroom, Guides Classroom Teacher, 1-19.

Yıldırım, A. ve Ş̧mşek, H. (2006). Sosyal bilimlerde nitel araştırma yöntemleri. (6. bsm). Ankara: Seçkin Yayıncılık

\section{Kaynakça Bilgisi / Citation Information}

Tutkun, C., Aydın-Kılıç, Z.N., Balcı, A. ve Kök, M. (2019) Okul öncesi öğretmenlerinin alan gezisi etkinliğine yönelik görüşlerinin incelenmesi. OPUS-Uluslararası Toplum Araştırmaları Dergisi, 14(20), 469-487. DOI: 10.26466/opus.571498 